\title{
The German Social Security System for Farmers
}

\author{
Erich Koch
}

\begin{abstract}
On the one hand, the complex, constantly evolving system of German Agricultural Social Insurance guarantees each individual insured person comprehensive protection under social insurance law comparable to that for the general population. On the other hand, the state supports not only farms but agriculture as an economic sector as a whole with a reliable and massive financial contribution. The history, tasks, responsibilities, benefits, financing and organisational structure will be presented as well as prevention, special programmes and international relations. In doing so, all four branches of the German Agricultural Social Insurance System are dealt with by means of the descriptive method.
\end{abstract}

Keywords: Agricultural Accident Insurance, Agricultural Health Insurance, Agricultural Long-term Care Insurance, Agricultural Social Insurance, Old-age Insurance for Farmers.

Erich Koch, Director of the Administration and Communication Division of SVLFG, Germany. 


\section{Introduction, historical development}

Agricultural Social Insurance is an independent branch of the German social insurance system. It has developed and completed itself over more than 130 years in stages and only partially parallel to the general social insurance system. Simultaneously with the establishment of the accident insurance organised by the professional associations ${ }^{1}$, the independent Agricultural Accident Insurance was initially founded on the basis of the general statutory accident insurance, at that time as an insurance exclusively for employees. The development towards entrepreneurial insurance was initiated by possibilities for voluntary and statutory insurance of agricultural entrepreneurs and brought about by the uniform accident insurance of agricultural and forestry entrepreneurs and their spouses living with them in a domestic community ${ }^{2}$. The integration of German agriculture into the European agricultural market was associated with questions of insurance for small and medium-sized farms against old age and illness, which were answered in 1957 with the introduction of old-age assistance for farmers as ${ }^{3}$ a special system based on professional status. Initially, this provided partial cover, in addition to the so-called 'Altenteil' (payment by the person taking over the farm to the person handing it over) and personal provision (savings and external accumulation of assets), for all agricultural entrepreneurs whose businesses formed the basis of their livelihoods based on land cultivation. The insurance of this group of persons against the risk of illness was followed in 1972 by the introduction of health insurance for farmers ${ }^{4}$. It was completed by the general introduction of social long-term care insurance, combined with the establishment of Agricultural Long-term Care Insurance funds on 1.1.1995 .

1. The Berufsgenossenschaften are institutions of statutory accident insurance and thus social insurance institutions. With the exception of the agricultural Berufsgenossenschaft, they are financed exclusively by contributions from employers. This is an essential difference to the other four branches of German social insurance, where contributions are levied on employers and employees. In return, employers are in principle exempt from any liability towards their employees. The Berufsgenossenschaften collect contributions on a pay-as-you-go basis to cover subsequent needs.

2. In 1939; Reich Law Gazette I 1939, 267.

3. By the law on old-age assistance for farmers, of 23.7.1957, BGBl. I, 1063. On the history E. Koch, A. Möller-Schlotfeldt [in:] Schulin, Handbuch des Sozialversicherungsrechts, Band 3 Rentenversicherungsrecht, $\$ 60$, Randnummer $5 \mathrm{ff}$. with further references.

4. By law on health insurance for farmers - KVLG of 10.8.1972, BGBl. I, 1433. On the history W. Volbers [in:] Schulin, Handbuch des Sozialversicherungsrechts, Band 1 Krankenversicherungsrecht, $₫ 57$, Randnummern $6 \mathrm{ff}$. with further references.

5. Extensive on this point Spitzenverbände der landwirtschaftlichen Sozialversicherung, Kurt-Wilhelm Noell and his thoughts and memories on the emergence, creation and realisation of agricultural social security in the context of national and international circumstances 1952 to 1977, monograph, 2002. In the new federal states, agricultural accident insurance and agricultural health insurance were introduced on 1.1.1991, and old-age insurance for farmers on 1.1.1995. 
As of 01.01.2013, a federal corporation under public law with self-administration was $^{6}$ established as the responsible body for the LSV. It bears the name Social Insurance for Agriculture, Forestry and Horticulture ${ }^{7}$. The nine agricultural Berufsgenossenschaften, agricultural old-age insurance funds, Agricultural Health Insurance funds, Agricultural Long-term Care Insurance funds (previous providers of Agricultural Social Insurance) as well as the central association of Agricultural Social Insurance ${ }^{8}$ were incorporated into the SVLFG9. This concluded a merger process that had been taking place in steps over decades, with the result of strengthening the federal government's ability to exert influence ${ }^{10}$.

\section{Tasks}

The SVLFG is responsible for Agricultural Accident Insurance, Old-age Insurance for Farmers, Agricultural Health Insurance and Agricultural Long-term Care Insurance ${ }^{11}$. Depending on which sector it represents, it is called the Agricultural Employer's Liability Insurance Association, the Agricultural Old Age Insurance Fund, the Agricultural Health Insurance Fund or the Agricultural Long-Term Care Insurance Fund ${ }^{12}$. SVLFG does not only have to apply agricultural social (special) $\operatorname{law}^{13}$; it also has to follow the codified general principles of social law ${ }^{14}$.

6. $\$ 1$ Law on the Establishment of the Social Insurance for Agriculture, Forestry and Horticulture (SVLFGG), of 12.04.2012, Federal Law Gazette I, 579. Although designed as an autonomous system with self-administration by elected representatives of the profession, there are nevertheless possibilities for state influence. Governmental influence takes place below the legislative level indirectly through the supervision by the Federal Insurance Office (according to $\$ 90$ paragraph 1 SGB IV), directly through the presence of representatives of the Federal Ministry of Labour and Social Affairs as well as the Federal Ministry of Food and Agriculture on the board of the SVLFG (according to $\$ 44$ paragraph 3a SGB IV). 7. This is the name of the authority. The name of the insurance scheme is "Agricultural Social Insurance". 8. The umbrella organisation of the agricultural social insurance, which was founded on 1 January 2009 and emerged from the Federal Association of the Agricultural Employers' Liability Insurance Associations, the General Association of the Agricultural Old-Age Insurance Funds and the Federal Association of the Agricultural Health Insurance Funds, was a federal public-law corporation with self-administration to which the individual agricultural employers' liability insurance associations, agricultural old-age insurance funds, agricultural health insurance funds and agricultural long-term care insurance funds belonged as members.

9. \$3 paragraph 1 SVLFGG.

10. J. Landgrebe, E. Sunder, Warum braucht die landwirtschaftliche Sozialversicherung nach 2001 noch eine zweite Organisationsreform?, "Soziale Sicherheit in der Landwirtschaft" 2007, p. 112.

11. $\$ 2$ SVLFGG.

12. See, for example, $\$ \$ 123$ SGB VII.

13. This refers to the provisions specific to agricultural social security, in particular in the ALG, the KVLG 1989 and the SGB VII.

14. See $\$ 2$ paragraph 2 SGB I. 
In the following, the individual branches of the German Agricultural Social Insurance will be presented in more detail.

\section{Agricultural Accident Insurance}

In the majority of cases, Agricultural Accident Insurance is a statutory entrepreneurial insurance which ${ }^{15}$, in its structure regulated by the Seventh Book of the Social Code (SGB VII), takes into account the operational structures of agriculture, which differ from those of commercial enterprises ${ }^{16}$. However, Agricultural Accident Insurance does not only provide ${ }^{17}$ insurance cover for agricultural entrepreneurs, but above all also for their assisting spouses or life partners ${ }^{18,19}$, other family members who work with them on a more than temporary basis, and those employed in agriculture, horticulture, forestry or viticulture with regard to occupational accidents and diseases.

The task of accident insurance - this applies in the same way to general accident insurance as to Agricultural Accident Insurance - is 1. to prevent occupational accidents and occupational diseases as well as work-related health hazards by all appropriate means, 2. to restore the health and performance of the insured persons by all appropriate means after the occurrence of occupational accidents or occupational diseases and to compensate them or their survivors by means of cash benefits ${ }^{20}$.

\section{Old-age Insurance for Farmers}

The second pillar of Agricultural Social Insurance is agricultural old-age insurance. With the law on Old-age Insurance for Farmers (ALG), which came into force on 1.1.1995 and replaced the law on old-age assistance for farmers (GAL) ${ }^{21}$, the 'pension insurance' of farmers was comprehensively reorganised ${ }^{22}$. The original aim of the oldage assistance, to provide the old-age divider (retired farmer) with a cash allowance for the old-age portion, was further developed in the direction of a partial security. The restriction to partial security takes into account that farmers are regularly secured in

15. Compare $\$ \$ 2$ paragraph 1 numbers $5 \mathrm{a}$ and $5 \mathrm{c}, 123$ SGB VII.

16. On the origin and development K. Mell [in:] Schulin, Handbuch des Sozialversicherungsrechts, Band 2 Unfallversicherungsrecht, $\$ 70$, Randnummern $1-36$ with further references.

17. $\$ 2$ paragraph 1 number 1 SGB VII.

18. $\$ 2$ paragraph 1 number 5a SGB VII.

19. $\$ 2$ paragraph 1 number 5 b SGB VII.

20. $\$ 1$ SGB VII.

21. Of 14.9.1965, Federal Law Gazette I, 1448.

22. Art. 1 of the Act on the Reform of Agricultural Social Security - Agricultural Social Security Reform Act 1995, ASRG 1995 - of 29.7.1994, Federal Law Gazette I, 1890. 
part by the value of their assets. This provides them with entitlements to old-age part payments, rent or proceeds from sales when they hand over the business. The system also pursues the goal of rejuvenating the stock of entrepreneurs and promoting the emergence of economically efficient enterprises. To this end, until a contrary decision by the Federal Constitutional Court in $2018^{23}$, the payment of pensions was made dependent on the surrender of the agricultural enterprise.

\section{Farmers' Health Insurance}

Farmers' Health Insurance is the third pillar of Agricultural Social Insurance in Germany. Above all farmers, their spouses and the family members working with them and entitled to maintenance and the old-age partitioners were included in the statutory health insurance from 1.10 .1972 by the Law on Health Insurance for Farmers (KVLG). By the Act on the Structural Reform of the Health Care System (GRG) of 20.12.1988 ${ }^{24}$, the health insurance of farmers was reformulated in the KVLG 1989.

In the area of benefit and contract law, there are extensive parallels to the general statutory health insurance ${ }^{25}$. In the area of financing, however, there are significant structural differences resulting from the group of insured persons ${ }^{26}$.

In contrast to the group of persons covered by the general statutory health insurance, those liable for insurance in the Agricultural Health Insurance cannot choose their health insurance fund ${ }^{27}$. Thus, the Agricultural Health Insurance fund is not a competitive health insurance fund ${ }^{28}$.

Like the Old-age Insurance for Farmers, the health insurance for farmers also pursues agricultural policy goals in addition to social policy goals. The adjustment and restructuring process in agriculture should also be covered by Agricultural Health Insurance in a socially acceptable way. Serious illnesses of the agricultural entrepreneur can cause costs which in many cases cannot otherwise be covered without interfering with the substance of the enterprise. This economic risk is to be countered with specific socio-political means of Agricultural Health Insurance, such as benefits for farm and household assistance ${ }^{29}$.

23. Federal Constitutional Court of 8.11.2018, 1 BvR 408/13 with comment E. Koch, jurisPR-SozR 23/2018.

24. BGBl. 1988 I, $2477 \mathrm{ff}$.

25. This is ensured in particular by $\$ 8$ paragraph 1 KVLG 1989.

26. More on this below.

27. Compare $₫ 173$ SGB V. The inclusion of farmers in compulsory insurance is constitutional; Federal Constitutional Court of 9.2.1977 - 1 BvL 11/74; Federal Social Court of 27.3.2006 - B 12 KR 28/05 B.

28. E. Koch, Is the LKK (still) a health insurance fund?, "Agrar- und Umweltrecht" 2019, p. 377.

29. Bundesministerium für Ernährung und Landwirtschaft, Bundeshaushaltsplan 2020, Einzelplan 10, www.bundeshaushalt.de/fileadmin/de.bundeshaushalt/content_de/dokumente/2020/soll/epl10.pdf, access 10.04.2021, p. 7. 


\section{Long-term care insurance}

Social long-term care insurance was introduced in 1994 as the last limited independent branch of social insurance ${ }^{30}$. By law, everyone who is insured under the statutory health insurance scheme is covered by the social long-term care insurance scheme. The providers of the social long-term care insurance are the long-term care insurance funds; their tasks are carried out by the health insurance funds. Accordingly, all persons who are also insured in the Agricultural Health Insurance are insured in the Agricultural Long-term Care Insurance. The group of insured persons in the Agricultural Health Insurance fund and in the Agricultural Long-term Care Insurance fund is therefore identical. The benefits - outpatient and inpatient; benefits in kind, cash and services - are basically the same as those of the general longterm care insurance ${ }^{31}$.

\section{Circle of insured persons}

With regard to the group of insured persons, a distinction must be made between Agricultural Accident Insurance, Old-age Insurance for Farmers and Agricultural Health Insurance/nursing care insurance. While the old-age insurance of farmers as well as the Agricultural Health Insurance and the long-term care insurance are primarily entrepreneurial insurances and include the group of persons of the (former) agricultural entrepreneurs and their family members, this group of persons is extended in the Agricultural Accident Insurance in particular to include the employees, i.e. the workers. This leads - together with a much broader concept of entrepreneur - to the fact that the number of insured persons in the Agricultural Accident Insurance is considerably larger. It also has an impact on the composition of the self-governing bodies. Workers' representatives are only allowed to participate in decisions in the area of responsibility of the accident insurance ${ }^{32,33}$.

30. By Act of 26.5.1994, Federal Law Gazette I, 2913.

31. See $\$ \$ 28 \mathrm{ff}$. SGB XI.

32. It is stated by the SVLFG to be 3.2 million, while the number of insured persons in agricultural health insurance at the beginning of 2020 was about 600,000 , www.svlfg.de.

33. See $₫ 44$ SFGB IV. 


\section{Responsibility of the Agricultural \\ Employer's Liability Insurance Association}

The responsibility of the agricultural employers' liability insurance association is regulated in SGB VII ${ }^{34}$. The companies listed exhaustively in the law include in particular:

1) enterprises engaged in agriculture and forestry, including horticulture and viticulture, inland fishing and beekeeping, as well as in landscape management serving the objectives of nature conservation and environmental protection;

2) undertakings in which livestock or breeding animals are kept for rearing, fattening or the production of animal products without cultivation of the land;

3) agricultural and forestry contractors;

4) park and garden maintenance and cemeteries;

5) hunts;

6) the chambers of agriculture and the professional agricultural associations;

7) undertakings which directly serve to safeguard, supervise or promote agriculture for the most part;

8) the SVLFG and its other institutions the supplementary pension fund and the supplementary pension scheme for employees in agriculture and forestry.

According to the legal definition ${ }^{35}$, the entrepreneur is the person who directly benefits or suffers from the result of the enterprise. The concept of entrepreneur applies to the entire statutory accident insurance, and thus also to the Agricultural Accident Insurance ${ }^{36}$. The spectrum of business forms covered by Agricultural Accident Insurance - from sole proprietorships to corporations - is therefore basically no different from commercial accident insurance. Many agricultural enterprises are still run as family businesses in the form of sole proprietorships or partnerships under civil law, especially in the old federal states. This corresponds to the model of rural agriculture propagated by the federal government, although it is not very distinctive ${ }^{37}$.

34. $\$ 123$ paragraph 1 SGB VII.

35. $\$ 136$ paragraph 3 number 1 SGB VII.

36. K. Mell [in:] Schulin, Handbuch des Sozialversicherungsrechts, Band 2 Unfallversicherungsrecht, $\$ 70$, Randnummern $40 \mathrm{ff}$.

37. Bundesministerium für Ernährung und Landwirtschaft, Perspektive Landwirtschaft Agrarpolitische Standortbestimmung, www.bmel.de/SharedDocs/Downloads/DE/Broschueren/AgrarpolitischeStandortbestimmung.pdf?_blob=publicationFile $\& v=5$, access 10.04 .2021 , p. 7: Our agricultural policy... stands for a rural agriculture that is ecologically, economically and socially oriented and regionally rooted. 


\section{Enterprises in agriculture and forestry in the narrower sense}

The core area of agricultural enterprises includes ${ }^{38}$ first of all the enterprises of agriculture and forestry including horticulture and viticulture, i.e. the areas which are referred to as 'primary production' in economic terms. The decisive factor in this respect is considered by case law to be soil cultivation, which includes all activities of not quite short duration, which are intended to raise and harvest soil plants in a predominantly planned manner ${ }^{39}$. Accordingly, an agricultural enterprise exists if the holding includes soil that is cultivated for the purpose of obtaining organic natural products. The concept of an enterprise does not presuppose an intention to make a profit ${ }^{40}$. The size of the agriculturally used area is also irrelevant. This interpretation has repeatedly given rise to legal disputes because users of smaller agricultural and forestry areas do not consider themselves 'entrepreneurs' and therefore doubted the admissibility of compulsory insurance subject to contributions, also from a constitutional point of view. Jurisprudence has rejected these doubts - above all with reference to the legislature's wide-ranging leeway ${ }^{41}$.

Against the background of this discussion, the legislator has seen fit to introduce a structurally unique provision in the field of statutory accident insurance on the insurance exemption for agricultural entrepreneurs of micro-enterprises (size up to 0.25 hectares; exception: special crops) $)^{42}$.

\section{Inland fishing and beekeeping enterprises}

The agricultural employers' liability insurance association is also responsible for inland fishing enterprises (fish farming, pond management, lake, stream and river fishing) and beekeeping ${ }^{43}$. Fish farming (as a type of agricultural enterprise) must therefore be geared towards useful fish, not ornamental fish ${ }^{44}$.

With regard to beekeeping, it is clear from the case law that this scope is not reached when keeping a single colony of bees, but is reached when keeping 25 colonies of bees ${ }^{45}$.

38. According to $\$ 123$ paragraph 1 number 1 SGB VII.

39. Federal Social Court of 31.1.1989 - 1 RU 30/88 with further evidence.

40. Compare $\$ 136$ paragraph 3 SGB VII.

41. E.g. Federal Social Court of 28.9.1999 - B 2 U 40/98 R. On the compulsory insurance of small forest owners Landessozialgericht Baden-Württemberg of 9.7.2015 -L 10 U 2233/14 with comment E. Koch, juris PraxisReport Sozialrecht, 5/2016.

42. $\$ 5$ SGB VII.

43. According to $\$ 123$ paragraph 1 number 1 SGB VII.

44. Kasseler Kommentar/Koch $₫ 123$ SGB VII margin no. 18.

45. See also Kasseler Kommentar/Koch $₫ 123$ SGB VII, margin no. 19. 


\section{Landscape maintenance company}

The agricultural employers' liability insurance association is also responsible for enterprises that serve the goal of nature conservation and environmental protec$\operatorname{tion}^{46}$. A landscape management enterprise requires area-oriented land management, which must comply with the requirements of the nature and environmental protection laws of the federal and state governments ${ }^{47}$.

\section{Livestock}

If livestock farming is carried out in connection with soil cultivation, it is an essential part (auxiliary enterprise) of the agricultural enterprise ${ }^{48}$. Furthermore, classical livestock farms are also $^{49}$ covered by the Agricultural Accident Insurance if they are operated without soil cultivation. However, these must be animals that are usually kept in agriculture (e.g. poultry, horses, pigs and cattle). This requirement is not met by farms used for breeding fur animals, ornamental fish and the like $e^{50}$.

\section{Agricultural and forestry contractors}

Agricultural and forestry contractors ${ }^{51}$ are independent commercial enterprises which, in return for payment, carry out agricultural or forestry activities in enterprises which would otherwise have to be carried out by the agricultural and forestry entrepreneurs themselves or with their own labour for the proper management of their enterprise.

\section{Park and garden maintenance and cemeteries}

Park $^{52}$ and garden maintenance companies are companies that maintain their own or third-party parks and gardens with the exception of the maintenance of house and ornamental gardens. The term cemetery covers all activities related to cemetery and funeral services, in particular maintenance work for the cemetery

46. According to $\$ 123$ paragraph 1 number 1 SGB VII.

47. On the state of opinion Kasseler Kommentar/Koch $\$ 123$ SGB VII margin numbers 20.

48. Within the meaning of $\$ 123$ paragraph 1 number 1 SGB VII. Compare $₫ 131$ paragraph 1 and 2 , sentence 2 SGB VII.

49. According to $\$ 123$ paragraph 1 number 2 SGB VII.

50. On individual cases, Kasseler Kommentar/Koch $₫ 123$ SGB VII, paragraphs $21 \mathrm{ff}$.

51. Within the meaning of $\$ 123$ paragraph 1 number 3 SGB VII.

52. Within the meaning of $\$ 123$ paragraph 1 number 4 SGB VII. 
facilities but also burial and transport of corpses, insofar as these activities are not carried out by independent funeral homes ${ }^{53}$.

\section{Hunts}

Agricultural enterprises also include hunting ${ }^{54}$. The term hunting enterprise includes all activities connected with the practice of hunting. It is not limited to hunting activities in the narrower sense, but also includes all activities serving hunting, such as maintenance of raised hide and hunting huts, feeding of game and management of game fields ${ }^{55}$.

\section{Other agricultural enterprises}

The Agricultural Employer's Liability Insurance Association is also responsible for: - the chambers of agriculture and the professional agricultural associations ${ }^{56}$,

- Enterprises which directly serve the safeguarding, supervision or promotion of agriculture $^{57}$,

- the institutions of the Agricultural Social Insurance, their associations and their other institutions, as well as the supplementary pension fund and the supplementary pension scheme for employees in agriculture and forestry ${ }^{58}$.

\section{Insured persons - overview}

The group of insured persons in Agricultural Accident Insurance includes employees $^{59}$, entrepreneurs of an agricultural enterprise and their spouses or life partners working in the enterprise ${ }^{60}$, family members working in the agricultural enterprise on a more than temporary basis ${ }^{61}$, self-employed persons regularly working in corporations or partnerships like entrepreneurs ${ }^{62}$, persons working on a voluntary

53. See also Kasseler Kommentar/Koch $₫ 123$ SGB VII, paragraph $24 \mathrm{f}$.

54. $\$ 123$ paragraph 1 number 5 SGB VII.

55. Kasseler Kommentar/Koch $\$ 123$ SGB VII margin no. 25 with further references.

56. $\$ 123$ paragraph 1 number 6 SGB VII.

57. $\$ 123$ paragraph 1 number 7 SGB VII.

58. $\$ 123$ paragraph 1 number 8 SGB VII. On all Kasseler Kommentar/Koch $\$ 123$ SGB VII margin numbers $26 \mathrm{ff}$.

59. \$2 paragraph 1 number 1 SGB VII.

60. $\$ 2$ paragraph 1 number 5a SGB VII.

61. $\$ 2$ paragraph 1 number 5 b SGB VII.

62. $\$ 2$ paragraph 1 number $5 \mathrm{c}$ SGB VII. 
basis in enterprises for the protection, supervision or promotion of agriculture ${ }^{63}$ and persons working on a voluntary basis in professional agricultural associations ${ }^{64}$.

\section{Insured persons in the old-age insurance scheme for farmers}

The group of persons insured in the old-age insurance of farmers is not identical to that of the Agricultural Accident Insurance. There are a number of differences which result in the number of persons insured under the old-age insurance scheme for farmers being considerably smaller ${ }^{65}$.

\section{Insured farmers}

The central concept for compulsory insurance in Old-age Insurance for Farmers is that of the self-employed farmer. Of the agricultural enterprises that are covered by the Agricultural Accident Insurance, only enterprises that cultivate the soil are eligible for the old-age insurance of farmers. Animal husbandry only counts as agriculture if it is connected with land cultivation. Enterprises that are operated without the intention of making a sustainable profit are excluded from compulsory insurance, in contrast to Agricultural Accident Insurance ${ }^{66}$.

Not every agricultural enterprise that is aimed at land cultivation leads to compulsory insurance for the entrepreneur running the enterprise. Rather, the prerequisite is the achievement of a minimum size ${ }^{67}$. The minimum size is the agricultural counterpart to the marginal earnings threshold in the rest of the social insurance system; it limits what is to be regarded as serious commercial activity. According to a decision of the representative assembly of the SVLFG, the minimum size ${ }^{68}$ is 8 hectares for agricultural land, 75 hectares for forestry and 2 hectares for viticulture as of $2014^{69}$.

63. $\$ 2$ paragraph 1 number 5 d SGB VII.

64. $\$ 2$ paragraph 1 number 5e SGB VII.

65. While the number of insured persons in the agricultural accident insurance is given as 3.2 million, the number of insured persons in the old-age insurance of farmers was less than 180,000 at the beginning of 2020. This number is lower than the number of persons exempted from compulsory insurance. The number of pension recipients is about three times higher than the number of insured persons; SVLFG, www.svlfg.de, access 10.04.2021.

66. Pursuant to section 1(7) ALG.

67. Within the meaning of $\$ 1(5)$ ALG.

68. On this, Federal Social Court of 27 May 2004 - B 10 LW 16/02 R with comment Koch, juris PraxisReport Sozialrecht, 40/2004.

69. For other crops and production methods, see SVLFG, Mindestgroessenbeschluss der landwirtschaftlichen Alterskasse, https://cdn.svlfg.de/fiona8-blobs/public/svlfgonpremiseproduction/3156496d14eea693/855b44dd69c8/Mindestgroessenbeschluss_2014.pdf. 


\section{Independent protection of the spouses}

The spouse of a farmer - usually the wife - becomes a farmer subject to compulsory insurance by way of fiction if both spouses do not live permanently separated and the spouse is not fully incapacitated for work ${ }^{70}$. Constitutional objections to this regulation, which is one of the central concerns of the reform of the law on Old-age Insurance for Farmers, have been rejected by the highest courts ${ }^{71}$.

\section{Employee family members}

Family ${ }^{72}$ members who work for the company are only insured under the old-age insurance scheme for farmers if the entrepreneur himself fulfils the conditions for compulsory insurance as a farmer. Working in a small agricultural enterprise that does not reach the minimum size cannot therefore trigger compulsory insurance. The relationship of kinship or affinity must be to a farmer - in the case of enterprises run by several entrepreneurs, to at least one of the co-entrepreneurs - or to the spouse of the farmer or co-entrepreneur.

The full-time employment of the family member is of central importance for compulsory insurance ${ }^{73}$. For socio-political reasons, the term 'full-time employment' is defined differently for family members than for entrepreneurs. As a result, lower requirements are imposed, which are, however, more extensive than those required for the inclusion of family members in the compensation system of the Agricultural Accident Insurance. In practice, the standards summarised in principles ${ }^{74}$ are applied, which have been developed for the compulsory insurance of the same group of persons in the Agricultural Health Insurance ${ }^{75}$. These principles assume full-time employment if the regular weekly working time in the enterprise is at least 15 hours or the employment is not of subordinate economic importance.

70. $\$ 1$ paragraph 3 sentence 1 ALG.

71. Federal Social Court of 12.2.1998 - B 10/4 Lw 9/96 R; Federal Social Court of 25.11.1998 - B 10/Lw 10/97 R and 8/98 R.; Federal Constitutional Court of 9.12.2003 - 1 BvR 558/99; D. Böttger, Verfassungsmäßigkeit der Pflichtversicherung der Landwirtsehegatten in der Alterssicherung der Landwirte - Anmerkungen zum Beschluss des Bundesverfassungsgerichts vom 9. Dezember 2003, Az. 1 BvR 558/99, "Soziale Sicherheit in der Landwirtschaft" 2004, p. 398.

72. Within the meaning of section 1(1)(2) in conjunction with section 1(8) ALG. $\$ 1$ paragraph 8 ALG.

73. Section 1(8) ALG.

74. Re $\$ 2$ paragraph 4 KVLG 1989.

75. Principles for assessing the main occupation within the meaning of section 2(4) sentence 1 of the KVLG 1989 of family members working in agriculture (Mifa-Hauptberuflichkeits-Grundsätze LKV) of 02.10.2018; SVLFG, www.svlfg.de, access 10.04.2021. 


\section{Exemption from insurance, exemption from compulsory insurance and voluntary continued insurance}

The regulations on the group of insured persons are completed by regulations on exemption from insurance, exemption from compulsory insurance and voluntary insurance.

Farmers and family members working with them are exempt from insurance by law before they reach the age of 18 and after they reach the standard age limit, i.e. they are exempt from compulsory insurance ${ }^{76}$. Family members who are also agricultural entrepreneurs are also exempt from insurance ${ }^{77}$. The possibility of exemption due to non-agricultural income has already been discussed (see above). Those who are obliged to pay pension insurance because of bringing up children, caring for children or doing military or civilian service also have a right to exemption ${ }^{78}$. same applies to farmers who become compulsorily insured in the old-age insurance scheme for farmers for the first time less than 15 years before reaching the standard retirement age. The right ${ }^{79}$ to voluntary insurance is only granted to spouses of former farmers ${ }^{80}$ not, however, to former assisting family members. Voluntary continued insurance can only be exercised by former farmers ${ }^{81}$.

\section{Insured persons in the Agricultural Health Insurance scheme}

The persons insured in the agricultural health insurance are largely identical to the previously explained group of persons protected in the old-age insurance of farmers ${ }^{82}$.

\section{Insured persons in long-term care insurance}

The group of insured persons is linked to the persons insured under the KVLG $1989^{83}$. It therefore basically consists of persons insured under the Agricultural Health Insurance scheme.

76. According to $\$ 2$ number 1 letter a ALG.

77. $\$ 2$ number 3 ALG.

78. Pursuant to section 3, paragraph 1, numbers 2 - 4 ALG. Federal Social Court of 5.10.2006 - B 10 LW 6/05 R with comment Koch, juris PraxisReport Sozialrecht, 3/2007.

79. $\$ 3$ paragraph 3 ALG.

80. $\$ 4$ ALG.

81. $\$ 5$ ALG.

82. See $\$ 2 \mathrm{ff}$. KVLG 1989 .

83. According to $₫ 20$ paragraph 1 sentence 2 number 3 SGB XI. 


\section{Services}

The benefits are provided according to the respective requirements in the individual branches of Agricultural Social Insurance. The volume of benefits amounts to over 7 billion euros in $2020^{84}$.

\section{Agricultural Accident Insurance benefits}

The benefit system of the agricultural accident insurance has only a few, but nevertheless significant differences compared to the general accident insurance. These include, for example, that a self-employed agricultural entrepreneur is only entitled to an injury pension after a reduction in earning capacity of $30 \%$, whereas this is the case for other insured persons from a reduction in earning capacity of $20 \%$. A distinction ${ }^{85}$ must be made between rehabilitation benefits, which are intended to remedy or mitigate the consequences of the accident, and cash benefits, in particular the injury pension. The amount of this benefit is considerably lower for farmers and spouses or partners working in the enterprise than in commercial accident insurance, because the basis for the assessment of the benefit is not the individual annual earnings, but a fixed ${ }^{86}$ annual earnings amount, which is generally adjusted annually $^{87}$. For assisting family members, the annual earnings are set at the level of the minimum annual earnings ${ }^{88}$.

During in-patient treatment, agricultural entrepreneurs who run a business of minimum size receive farm ${ }^{89}$ and household assistance as a specific benefit of the Agricultural Accident Insurance ${ }^{90}$, which is intended to compensate for the entrepreneur's absence from the agricultural business. In principle, no injury benefit can be granted in addition to farm and household assistance; exceptionally, it may be paid instead of farm and household assistance ${ }^{91}$.

84. SVLFG, Die SVLFG kompakt in Zahlen, https://www.svlfg.de/svlfg-kompakt-in-zahlen (with income and expenditure by branch of agricultural social insurance), access 10.04.2021.

85. Federal Social Court of 20.3.2018 - B 2 U 6/17 R with comment Koch, juris PraxisReport Sozialrecht, 21/2018.

86. According to $\$ 93$ paragraph 1 SGB VII.

87. According to $\$ 95$ SGB VII.

88. Pursuant to $\$ 93$ paragraph 3 SGB VII in conjunction with $₫ 85$ paragraph 1 SGB VII. $₫ 85$ paragraph 1 SGB VII.

89. Within the meaning of Section 1(2) ALG.

90. Under the conditions of $\$ 54$ SGB VII.

91. According to $\$ 55$ SGB VII. 


\section{Benefits of the old-age insurance scheme for farmers}

The benefits provided are rehabilitation benefits, occupational and household assistance as well as pensions and other current cash benefits including contribution subsidies $^{92}$.

\section{Benefits for rehabilitation, occupational and household assistance}

The old-age insurance scheme for farmers provides medical and supplementary rehabilitation benefits to counteract or overcome the effects of an illness or a physical, mental or psychological disability on the insured person's ability to work and thereby prevent impairments to the insured person's ability to work or their premature withdrawal from working life, or to reintegrate them into working life as permanently as possible. Rehabilitation benefits have priority over pension benefits. The prerequisite for the granting of benefits is that the personal and insurance law requirements are met ${ }^{33}$.

Farm and household assistance ${ }^{94}$ is one of the special and important types of benefit in agricultural social security. It was introduced in recognition of the fact that farmers, in particular, can only claim rehabilitation benefits and comparable other measures if the continued operation of the agricultural enterprise is ensured for the duration of these measures. Farm or household assistance may be provided in particular if the farmer is unable to work or is accommodated away from home for medical or other services. Other reasons for use are pregnancy and maternity. If the farmer dies, the surviving spouse may claim farm or household assistance if he or she continues the business ${ }^{95}$. Substitute worker is provided as farm or household help or the costs of a substitute worker procured by the farmer himself/herself are reimbursed at an appropriate level ${ }^{96}$.

92. In detail: E. Koch, A. Möller-Schlotfeldt [in:] Schulin, Handbuch des Sozialversicherungsrechts - Band 3 Rentenversicherungsrecht, $\$ 61$.

93. See below.

94. $\$ \$ 10,36,37,39$ ALG.

95. For the calculation of the deductible in the case of farm assistance after the death of the farmer, compare Federal Social Court of 23.9.2004 - B LW 1/04 R with comment Koch, juris PraxisReport Sozialrecht, $1 / 2005$.

96. \$10 paragraph 3 ALG. 


\section{Pensions in the Old-age Insurance scheme for farmers}

The Old-age Insurance scheme for farmers grants the following pensions if the other requirements are met: Standard old-age pension for former farmers and family members working with them, early old-age pensions, pensions due to reduced earning capacity, widows' and widowers' pensions, orphans' pensions ${ }^{97}$.

Pension benefits under the old-age insurance scheme for farmers require the fulfilment of a qualifying period. The waiting period is 15 years for the standard old-age pension and the early old-age pension for spouses ${ }^{98}, 35$ years for the early old-age pension ${ }^{99}, 5$ years for pensions due to reduced earning capacity and death. Contribution periods and, under certain conditions, periods completed under other social security schemes are counted towards the qualifying period. In addition, the insured event must have occurred. The insured event occurs when the insured person reaches a certain age ${ }^{100,101}$. Other insured events are the occurrence of a reduction in earning capacity and the death of the insured person ${ }^{102}$.

The monthly amount of the expected old-age or disability pension is calculated according to the formula: Increase number $\mathrm{x}$ pension type factor $\mathrm{x}$ general pension value $=$ monthly pension. Unlike the statutory pension insurance, the old-age insurance of farmers does not know any further elements that determine the individual pension amount due to the levying of standard contributions and the resulting standard benefits per contribution month. The incremental value is calculated by multiplying the number of calendar months with contribution periods, a credited period and periods of receipt of a pension due to reduced earning capacity that coincide with a credited period and credited periods prior to the start of this pension by the relevant factor ${ }^{103}$. The general pension value ${ }^{104}$ is the pension yield for one year of contribution payment (current pension value in the statutory pension insurance ${ }^{105}$. It changes on 1 July of each year according to the percentage by which the current pension value in the statutory pension

97. $\$ \$ 11-15$ ALG.

98. Pursuant to section 12(1) ALG.

99. According to $\$ 12$ paragraph 2 ALG. Although this type of pension was introduced as early as 1.1.2008, it only gained significance from 2012 (start of the increase in the standard age limit from 65 to 67 years of age, $\$ 87$ a ALG); Wirth, SdL 2006, Anhebung der Altersgrenzen in der Alterssicherung der Landwirte und weitere Änderungen im Gesetz über die Alterssicherung der Landwirte, 261.

100. $\$ \$ 17,18$ ALG.

101. Sections 11(3), 87a ALG.

102. $\$ \$ 13 \mathrm{ff}$. ALG.

103. Rombach, Alterssicherung der Landwirte, pages $110 \mathrm{ff}$.

104. Section 23(4) ALG.

105. $₫ 68$ paragraph 1 SGB VI. 
insurance is changed. For each month for which the insured person claims an old-age pension prematurely, the general pension value is reduced by a discount. The average monthly agricultural old-age pension of a former agricultural entrepreneur is about 500 Euros $^{106}$.

\section{Contribution subsidies}

Because the contribution, like the pension amount, is set without regard to the income earned from the insured activity, low-income insured persons may be overburdened with its payment. The ALG therefore provides for entitlements to contribution subsidies, structured as social benefit entitlements, for those compulsorily insured persons whose annual income does not exceed a threshold amount per year ${ }^{107}$ the sum of the positive income shown in the last available income tax assessment is decisive ${ }^{108}$. In the case of spouses, the income is ${ }^{109}$ added together and divided equally. The contribution subsidy is paid monthly, due at the same time as the contribution $^{110}$ and offset against it. The contribution subsidy for ${ }^{111}$ assisting family members is half of the subsidy for farmers ${ }^{112}$.

\section{Bridging allowance}

In the event of the death of an insured farmer, surviving spouses shall receive a bridging allowance to facilitate the continued operation of the farming enterprise, for a maximum period of 3 years, calculated like a standard old-age pension on the basis of the contributions paid by the deceased ${ }^{113}$. Entitlement to a bridging allowance is suspended during the period in which farm and household assistance is provided in the event of the farmer's death ${ }^{114}$.

106. $\$ 23$ paragraph $8-10$ ALG.

107. $\$ 32$ ALG.

108. Section 32(3) ALG.

109. Pursuant to section 32(2) ALG.

110. Section 34(1) ALG.

111. Section 70(2) ALG.

112. On the amount of the contribution subsidy $\$ 33$ ALG.

113. $\$ 38$ ALG.

114. $\$ 38$ paragraph 4 ALG. On the exemption from compulsory insurance of the spouse of a female farmer when receiving bridging allowance; Federal Social Court of 10.5.2007 - B 10 LW 7/05 R with comment Koch, juris PraxisReport Sozialrecht 1/2008. 


\section{Benefits of the Agricultural Health Insurance}

The benefits of the Agricultural Health Insurance are largely identical to those of the general health insurance. From a legal point of view, this results from the fact that a general clause in the KVLG 1989 refers to the provisions of the law of Chapter 3 of the Social Code Book $V^{115}$. This means that insured persons of the Agricultural Health Insurance fund basically receive all benefits that are also provided for insured persons of other health insurance funds. These include medical, dental and psychotherapeutic treatment, the provision of medicines, dressings, remedies and aids, home nursing, hospital treatment and medical rehabilitation services.

The most important agricultural-specific benefit to prevent income losses due to illness is the farm and household assistance ${ }^{116}$. As a benefit of farm and household assistance, the Agricultural Health Insurance Fund either provides a substitute worker employed by it or by a contractual partner, or reimburses the costs for a substitute worker procured by itself at an appropriate level ${ }^{117}$.

\section{Long-term care insurance benefits}

The regulations under long-term care insurance law for persons insured in agriculture - in particular the entitlements to benefits - result directly from the Eleventh Book of the Social Code (SGB XI). There are practically no special features in terms of benefit law compared to the general social long-term care insurance.

\section{Prevention}

From the point of view of the various branches of Agricultural Social Insurance, prevention means prevention of accidents at work and occupational diseases (in accident insurance), prevention of diseases (in health insurance and old-age insurance).

The prevention of occupational accidents has been a main purpose of Agricultural Accident Insurance from the very beginning. It is not possible here to even begin to describe all the prevention measures, tools and campaigns ${ }^{118}$. The local supervision of the member companies and the insured persons of the

115. $\$ 8$ paragraph 1 KVLG 1989.

116. $\$ \$ 9-11$ KVLG 1989.

117. According to $\$ 11$ KVLG 1989.

118. An overview is provided by the SVLFG's annual prevention report; see www.svlfg.de. 
Agricultural Accident Insurance is carried out nationwide by the three service centres. The supervisors advise the member companies and the insured persons on site in all matters of occupational safety and health protection and monitor accident prevention in all work areas and work procedures. They also investigate accidents in order to accurately record areas of danger and develop measures to prevent the hazards. In addition to classic accident prevention, workplace health promotion is also a prevention mandate of the statutory accident insurance. Within this framework, the field workers also assess workplaces with regard to health hazards. Various offers, courses and seminars have the following focal points, among others: safe cattle husbandry, safe maintenance, healthy eating, sun protection, back health ${ }^{119}$.

Special prevention measures have been developed for insured persons of the Landwirtschaftliche Alterskasse in recent years. 'Strong against stress - stress prevention programme' is one of them ${ }^{120}$. The ever faster changing world of work has brought about a change in work-related stress. Whereas in the past the focus was on physical stress, today it is increasingly mental stress that contributes to health problems. Against this background, the first two-week prevention programme 'Strong against Stress' took place in January 2018 as part of a study. The aim is to develop, implement and evaluate a high-quality prevention programme on stress prevention and health promotion with subsequent telephone coaching in order to perpetuate the effects achieved. The seven programmes in 2018 involved actively employed insured persons of the Agricultural Old Age Insurance Fund who are at risk of developing health impairments due to increased stress.

The prevention offers of the statutory health insurance funds and thus also of the Agricultural Health Insurance Fund according to the 'individual approach'121 are directed at individuals with the aim of supporting them in desired changes in health behaviour and to teach them health-related skills. The measures are basically carried out in groups and are intended to motivate and enable the insured persons to actively prevent illnesses. The aim is to maintain and develop a healthy lifestyle, especially through regular exercise, proper nutrition and relaxation techniques. The primary prevention offers can cover several fields of action at the same time. For example, many course concepts take into account the well-known connection between exercise and nutrition. Likewise, measures are offered that combine the promotion of exercise with methods of stress reduction and relaxation. The criteria

119. For more information, see www.svlfg.de. 120. See also in the SVLFG prevention report. 121. According to $\$ 20 \mathrm{SGB} V$. 
for individual course offers are defined in the GKV prevention guidelines ${ }^{122}$. The examination of the prevention courses is carried out centrally, nationwide and across all types of health insurance funds by the Central Prevention Examination Office. Courses in the field of physical activity are particularly popular with SVLFG policyholders. The use of courses in the field of stress management has increased steadily in recent years ${ }^{123}$.

\section{Organisation}

The SVLFG is the responsible body for Agricultural Social Insurance. It is the legal successor to the agricultural Berufsgenossenschaften, agricultural old-age insurance funds, Agricultural Health Insurance funds, Agricultural Long-term Care Insurance funds (previous providers of Agricultural Social Insurance) and the central association of Agricultural Social Insurance ${ }^{124,125}$. The SVLFG is a public corporation with self-administration. The representative assembly, which is elected every six years, is the supreme decision-making body and, as a legislative body, the parliament of the SVLFG. Its main tasks include passing resolutions on the statutes, issuing accident prevention regulations for the social accident insurance institution, adopting the budget, approving the annual accounts and discharging the board of directors and the management. The representative assembly of the SVLFG comprises 60 members, including 20 representatives of employees, 20 representatives of self-employed persons without outside labour and 20 representatives of employers. The representative assembly elects the board of directors and the management.

The honorary board of directors administers the insurance carrier together with the management, which is responsible for the day-to-day administrative business. The SVLFG board consists of 15 members and is elected by the representatives' assembly. Representatives of the Federal Ministry of Food and Agriculture and the Federal Ministry of Labour and Social Affairs attend the meetings of

122. GKV-Spitzenverband, Leitfaden Prävention, https://www.gkv-spitzenverband.de/krankenversicherung/praevention_selbsthilfe_beratung/praevention_und_bgf/leitfaden_praevention/leitfaden_praevention.jsp, access 10.04.2021.

123. These courses accounted for around 74 per cent of all course attendance in 2018, SVLFG, Präventionsbericht 2018 Sicherheit und Gesundheitsförderung, https://cdn.svlfg.de/fiona8-blobs/public/svlfgonpremiseproduction/8f9a30038d0cf905/51fefbc582f2/broschuere-praeventionsbericht-2018.pdf, p. 34, access 10.04.2021.

124. Pursuant to Article 3(1) SVLFGG.

125. According to Article 1 SVLFGG. 
the Board in an advisory capacity. The Executive Board decides in particular on issues of fundamental importance. Among other things, it decides on the organisational structure of the SVLFG, makes personnel decisions, initiates prevention and health services, draws up the budget and prepares recommendations for resolutions for the representatives' assembly. The SVLFG is supervised by the Federal Social Security Office ${ }^{126}$.

The SVLFG has a two-tier structure. The head office is located in Kassel. The head offices of all former Agricultural Social Insurance institutions became branch offices. Offices are located in Kiel, Hanover, Münster, Bayreuth, Landshut, Darmstadt, Hoppegarten, Stuttgart ${ }^{127}$.

\section{Funding}

In addition to the traditional sources of financing in social insurance (contributions and other revenues ${ }^{128}$ ), it is the federal government that contributes a considerable share of the financing of the total expenditure of the sub-sectors in the area of Agricultural Social Insurance from tax revenues. Expenditure on agricultural social policy is the most significant factor in the budget of the responsible federal ministry ${ }^{129}$.

The 2020 federal budget provides for expenditure totalling 362 billion euros. Of this, approx. 4 billion will be spent on Agricultural Social Insurance alone ${ }^{130}$. This means that agriculture, and agricultural entrepreneurs in particular, are held in particularly high esteem ${ }^{131}$. With the social security of agricultural entrepreneurs and their families, the German legislator - like some other European countries ${ }^{132}$ - supports

126. E. Koch, Is the LKK (still) a health insurance fund?, "Agrar- und Umweltrecht" 2019, p. 377.

127. Article 4(1) SVLFGG.

128. $\$ 20$ SGB IV.

129. Bundesministerium für Ernährung und Landwirtschaft, Agrarsozialpolitik, https://www.bmel.de/ DE/Landwirtschaft/Foerderung-Agrarsozialpolitik/Agrarsozialpolitik/sozialpolitik_node.html, access 10.04.2021.

130. Bundesministerium für Ernährung und Landwirtschaft, Bundeshaushaltsplan 2020, Einzelplan 10, https://www.bundeshaushalt.de/fileadmin/de.bundeshaushalt/content_de/dokumente/2020/soll/Epl_ Gesamt_mit_HG_und_Vorspann.pdf, access 10.04.2021.

131. B. Schmidt, Auf- und Ausbau des agrarsozialen Sicherungssystems im Zusammenwirken von sozialer Sicherung, Änderungen der Agrarstrukturen und finanzieller Unterstützung des Bundes, "Soziale Sicherheit in der Landwirtschaft" 2011, p. 53.

132. All agricultural social security systems in Europe - in Finland, France, Austria and Poland - have a state share of funding that is significantly higher than in Germany. On the systems, E. Koch, Aspekte der Agrarsozialversicherungssysteme in Europa, "Soziale Sicherheit in der Landwirtschaft" 2011, p. 171. 
farming families in the long term. It is involved to a relatively much greater extent than in general social insurance ${ }^{133}$.

Proportionate federal funding takes account of structural change in agriculture through the granting of federal funds in Agricultural Accident Insurance, the federal government's deficit liability in Old-age Insurance for Farmers ${ }^{134}$, and through the basic financing of old-age divisors in Agricultural Health Insurance ${ }^{135}$. At the same time, it ensures that the federal government can react to structural problems in agriculture.

\section{Financing of Agricultural Accident Insurance}

The expenses of the Agricultural Employer's Liability Insurance Association are basically borne by the currently approx. 1.5 million members. The contribution to the Agricultural Employer's Liability Insurance Association is calculated according to the principle of retrospective coverage of needs. The expenses of the past business year are collected in the following year via the contribution invoices. The contribution consists of a basic contribution and a risk-oriented contribution ${ }^{136}$. The basic contribution is levied to cover non-risk-related expenses (70\% of prevention costs, full asset expenses, administrative costs less asset income and income from fees and certain contributions). The minimum basic contribution in 2020 is 87.50 euros and the maximum basic contribution is 350.00 euros. The risk-based contribution component is used to finance the benefit expenses arising from occupational accidents (for example, treatment costs and injury pensions). Two elements are used for the calculation, namely the working time (labour demand, labour value) as a potential risk and the realised risk in the form of the actual benefit expenses of one year per risk group and within the risk group per production process ${ }^{137}$. For this purpose, 16 risk groups (for example, arable land, cattle farming, hunting) have been formed.

133. The Federal Government contributes $€ 45.2$ billion to the expenditure of the statutory pension insurance amounting to $€ 211.6$ billion; Bundesministerium für Arbeit und Soziales, Themen aus dem Bereich Gesetzliche Unfallversicherung, https://www.bmas.de/DE/Themen/Soziale-Sicherung/finanzdaten-sozialversicherung.html, access 10.04.2021.

134. $\$ 78 \mathrm{a}$ ALG.

135. Section 37(2) KVLG 1989.

136. The expert opinion of Prof. E. Bahrs on the scale of contributions can be found in "Beitragsmaßstab für die Unfallversicherung in der Landwirtschaft, im Forst sowie im Gartenbau" at https://cdn.svlfg.de/fiona8-blobs/public/svlfgonpremiseproduction/2d2bcc84ce9e5d3b/2e7c382de8f3/gutachten-beitrag-bg.pdf. 137. See also: SVLFG, Die Beiträge zur Landwirtschaftlichen Berufsgenossenschaft, https://www.svlfg.de/ beitrag-lbg. 
The use of federal funds is lower in Agricultural Accident Insurance than in the other insurance branches. In order to improve the income situation in agriculture, the federal government has been relieving the burden on eligible entrepreneurs since 1963 through voluntary subsidies. They replace part of the levy to be borne by the entrepreneurs, thus reducing the individual contribution of the entrepreneur and directly relieving him of operating costs. Those eligible for subsidies are primarily land-managing entrepreneurs whose annual contribution exceeds an annually set threshold (2020, 305 euros $)^{138}$. The subsidies are redefined annually by the Budget Act. This means that the Bundestag periodically decides on the question of subsidies. In 2020, they amount to 177 million euros ${ }^{139}$. Thus, in contrast to the other social insurance branches, the participation of the federal government is not regulated by agricultural social law.

\section{Financing of the old-age pension scheme for farmers}

The Federal Ministry of Labour and Social Affairs annually redefines the contribution to be paid by the insured entrepreneurs and promulgates it in the Federal Law Gazette. The contribution is the same for farmers and their spouses. In 2020, it will be 261 euros in western Germany and 244 euros in eastern Germany ${ }^{140}$. Half is payable for assisting family members. The contributions can be significantly reduced by the subsidies to the contribution to be granted by the Landwirtschaftliche Alterskasse at the expense of the Federation without reducing pension entitlements. The contributions to be paid for all persons liable to insurance on a farm are generally borne by the farmer. Spouses are entitled to a contribution subsidy as long as the total annual income of the spouses does not exceed 31,000 Euros. For single persons this is 15,500 euros. In addition to the aforementioned control instrument of setting the contributions, the federal legislator has decided to ensure long-term and thus sustainable financing. With the deficit liability of the federal government ${ }^{141}$, it takes over the shortfall between income and expenditure and thus bears the financial consequences of structural change in agriculture ${ }^{142}$. The share of tax revenues

138. Bundesministerium für Ernährung und Landwirtschaft, Bundeshaushaltsplan 2020, Einzelplan 10, www.bundeshaushalt.de/fileadmin/de.bundeshaushalt/content_de/dokumente/2020/soll/epl10.pdf, access 10.04.2021, p. 7 .

139. Ibidem, p. 9.

140. SVLFG, Versicherte Personen und Beitrag, www.svlfg.de/versicherte-personen-alterskasse, access 10.04.2021.

141. According to $\$ 78$ ALG.

142. See also: Bundesministerium für Ernährung und Landwirtschaft, the Federal Government's Status Report on Old-Age Insurance for Farmers, https://www.bmel.de/SharedDocs/Downloads/Landwirtschaft/ Agrar-Sozialpolitik/LageberichtAlterssicherung.pdf?_blob=publicationFile, access 10.04.2021. 
in the financing is currently about $80 \%$. The high participation of the federal government -2.4 billion euros in $2020^{143}$ - was also justified in the past by the fact that agricultural policy purposes are pursued by linking the granting of pensions to the company's levy ${ }^{144}$.

\section{Financing of Agricultural Health Insurance}

The Agricultural Health Insurance is financed by contributions, by subsidies from the Federation, the participation of the Federation in expenses and by other revenues ${ }^{145}$. In accordance with the principle of solidarity, the contributions are graduated according to contribution classes. This makes it possible to ensure full health insurance cover for all farmers on a solidarity basis with a contribution corresponding to their financial capacity ${ }^{146}$.

The Federal Government bears the costs of benefits for the old-age partitioners insured under the KVLG 1989, insofar as these costs are not covered by the contributions of the old-age partitioners and by the so-called solidarity surcharge ${ }^{147}$. By means of a solidarity surcharge ${ }^{148}$, the actively insured participate in the benefit expenses for the old-age partitioners. The federal funds serve primarily to alleviate the structural burdens on the insured in Agricultural Health Insurance ${ }^{149}$. The federal government contributes 1.5 billion euros ${ }^{150}$ to the financing of the Agricultural Health Insurance - the revenue and expenditure volume is approximately 2.7 billion euros in $2020^{151}$.

143. Bundesministerium für Ernährung und Landwirtschaft, Bundeshaushaltsplan 2020, Einzelplan 10, www.bundeshaushalt.de/fileadmin/de.bundeshaushalt/content_de/dokumente/2020/soll/epl10.pdf, access 10.04.2021, p. 9 .

144. Bundesministerium für Ernährung und Landwirtschaft, Bundeshaushaltsplan 2020, Einzelplan 10, www.bundeshaushalt.de/fileadmin/de.bundeshaushalt/content_de/dokumente/2018/soll/epl10.pdf, access 10.04.2021, p. 7; B. Schmidt, E. Sunder, E. Fleuth et all., Hofabgabeverpflichtung auf dem Prüfstand Konsequenzen aus dem Gutachten des Thünen-Instituts zur agrarstrukturellen Wirkung der Hofabgabeverpflichtung, "Soziale Sicherheit in der Landwirtschaft" 2013, p. 46.

145. Section 37(1) KVLG 1989.

146. $\$ 40$ KVLG 1989.

147. Pursuant to Section 37(2) KVLG 1989.

148. Section 38(4) KVLG 1989.

149. Bundesministerium für Ernährung und Landwirtschaft, Bundeshaushaltsplan 2020, Einzelplan 10, www.bundeshaushalt.de/fileadmin/de.bundeshaushalt/content_de/dokumente/2020/soll/epl10.pdf, access 10.04.2021, p. 7.

150. SVLFG, Haushaltsplan der Sozialversicherung für Landwirtschaft, Forsten und Gartenbau für das Haushaltsjahr 2020, http://intranet.svlfg.de/70_zentr_aufg/70_06_haushalt/0_haushaltsplan/haushaltsplan_2020.pdf, access 10.04.2021, Section 3 there.

151. Bundesministerium für Ernährung und Landwirtschaft, Bundeshaushaltsplan 2020, Einzelplan 10, www.bundeshaushalt.de/fileadmin/de.bundeshaushalt/content_de/dokumente/2020/soll/epl10.pdf, access 10.04.2021, p. 9. 


\section{Financing of long-term care insurance}

The contribution to long-term care insurance is levied on agricultural entrepreneurs and assisting family members in the form of a surcharge on the health insurance contribution ${ }^{152}$. The amount of this surcharge is determined by setting the respective contribution rate in long-term care insurance in relation to the average general contribution rate of statutory health insurance on a certain reference date and multiplying the result by the contribution to the Agricultural Health Insurance fund. In this way, the contribution structure of the Agricultural Health Insurance is mapped in the same way as the contribution structure of the general statutory health insurance for other groups of insured persons in the social long-term care insurance.

The expenditure of the Agricultural Care Insurance Fund was estimated at 787 million euros in 2020. Of this, the contributors have to raise about 200 million euros, the largest part otherwise coming from the general equalisation fund ${ }^{153}$.

\section{Actions and programmes}

It is an important goal of the SVLFG to motivate its insured to lead a healthy lifestyle and to help you stay healthy at work. It is not possible to describe all the campaigns and programmes in this regard here. As an example, the campaign 'Mit uns im Gleichgewicht' (With us in balance) with its online health training is presented: With GET.ON, a scientifically supported online self-help training ${ }^{154}$, insured persons can find help for the prevention of mental stress quickly, easily and anonymously. The evidence-based health training of GET.ON can reach insured persons early in the disease process of mental complaints and offers effective help online in the following seven topic areas: Stress, Mood, Diabetes and Depressive Disorders, Regeneration, Chronic Pain, Drinking Less Alcohol, Panic. The health trainings can be used independently at any time and any place. Thus, the insured do not have to visit a therapist. With the online self-help training, those affected have the opportunity to go through a training programme tailored to them via a secure access code. A personal trainer accompanies the participants by e-mail or, if desired, by telephone. This support takes place not only during the active training phase

152. $\$ 55$ paragraph 5 SGB XI.

153. SVLFG, Haushaltsplan der Sozialversicherung für Landwirtschaft, Forsten und Gartenbau für das Haushaltsjahr 2020, http://intranet.svlfg.de/30_stabsstellen/30stab07_haushalt/04_haushalt/0_haushaltsplan/ haushaltsplan-2020.pdf, Section 4 - LPV insurance branch, access 10.04.2021.

154. An overview is provided by the SVLFG's annual prevention report, see www.svlfg.de. 
( 6 to 8 weeks), but also in a results-stabilising phase up to 12 months after the training phase. A major advantage is that the training courses have been specially adapted to farms in agriculture, forestry and horticulture and thus individual needs and relevant problem areas could be taken into account.

\section{International cooperation}

Due to the limitation of responsibility to the territory of the Federal Republic of Germany, the SVLFG's relationship partners are initially and typically domestic. However, as there may be insurance issues and benefit claims when staying abroad, foreign contacts arise which are organised and handled in particular via the insurance branch-specific liaison offices ${ }^{155}$. This concerns both entrepreneurs who have businesses abroad and, for example, foreign persons who come to Germany as seasonal workers. In addition, the SVLFG is involved as a member in international associations. The cooperation primarily serves the further development of social security ${ }^{156}$. Moreover, with the growing importance of international legislation and jurisdiction, there is a recognised need for information and influence, especially at the level of the European Union. It makes sense to bundle interests. This can be done in a more social insurance branch-oriented way ${ }^{157}$ or include several or all insurance branches. The framework ${ }^{158}$ for action can be European ${ }^{159}$ or universal ${ }^{160}$.

For the SVLFG as a special occupational system, cooperation and joint representation with the other European agricultural social protection systems is particularly useful, in addition to active participation in the International Social Security Association $(\text { ISSA })^{161}$, the Association International de la Mutualité (AIM) ${ }^{162}$, European Social Insurance Platform (esip) ${ }^{163}$ and the European Forum of the Insurance against Accidents at Work and Occupational Diseases ${ }^{164}$. Currently, the SVLFG holds the presidency of

155. See $\$ 50$ ALG.

156. Compare for example Louro J. Carreno, Über den Nutzen der aktiven Mitgliedschaft in internationalen Vereinigungen von Sozialversicherungsträgern - zugleich eine Vorstellung des AIM-Positionspapiers zur Gesundheitsförderung und Krankheitsprävention, "Soziale Sicherheit in der Landwirtschaft" 2016, p. 31.

157. For example, within AIM or the European Forum.

158. This is the case within ENASP, esip and ISSA.

159. At the ENASP, at the esip.

160. At the ISSA and at the AIM.

161. International Association of Mutual Benefit Societies (AIM), www.aim-mutual.org, access 10.04.2021.

162. International Social Security Association (ISSA), www.issa.int, access 10.04.2021.

163. Maison Européenne de la Protection Sociale, www.esip.eu, access 10.04.2021.

164. European Forum of the Insurance against Accidents at Work and Occupational Diseases, www. europeanforum.org, access 10.04.2021. 
the European Network of Agricultural Social Protection Systems (ENASP) ${ }^{165}$. In addition, the diverse bilateral relations are also of great importance, especially for the further development of health and prevention services.

\section{Bibliography}

Böttger D., Verfassungsmäßigkeit der Pflichtversicherung der Landwirtsehegatten in der Alterssicherung der Landwirte - Anmerkungen zum Beschluss des Bundesverfassungsgerichts vom 9. Dezember 2003, Az. 1 BvR 558/99, "Soziale Sicherheit in der Landwirtschaft" 2004.

Carreno Louro J., Über den Nutzen der aktiven Mitgliedschaft in internationalen Vereinigungen von Sozialversicherungsträgern - zugleich eine Vorstellung des AIM-Positionspapiers zur Gesundheitsförderung und Krankheitsprävention, "Soziale Sicherheit in der Landwirtschaft" 2016.

Koch E., Ist die LKK (noch) eine Krankenkasse?, "Agrar- und Umweltrecht” 2019.

Koch E., Zur Verfassungsmäßigkeit der Hofabgabeklausel, juris PraxisReport Sozialrecht, 23/2018.

Koch E., Erhöhung der Mindest-MdE auf 30 vH für Verletztenrente in landwirtschaftlichen Unfallversicherung, juris PraxisReport Sozialrecht, 21/2018.

Koch E., Versicherungspflicht von Kleinwaldbesitzern in der landwirtschaftlichen Sozialversicherung, juris PraxisReport Sozialrecht, 5/2016.

Koch E., Aspekte der Agrarsozialversicherungssysteme in Europa, "Soziale Sicherheit in der Landwirtschaft" 2011.

Koch E., Befreiung von der Versicherungspflicht in der Alterssicherung der Landwirte, juris PraxisReport Sozialrecht, $1 / 2008$.

Koch E., Befreiung von der Versicherungspflicht nach $\$ 3$ Abs. 1 ALG, juris PraxisReport Sozialrecht, 3/2007.

Koch E., Berechnung der Selbstbeteiligung bei Betriebshilfe nach Tod des Landwirts, juris PraxisReport Sozialrecht, $1 / 2005$.

Koch E., Herstellung des Einvernehmens des Gesamtverbandes der landwirtschaftlichen Alterskassen zur Neufestsetzung der Mindestgröße i.S.v. $\$ 1$ Abs. 5 ALG, juris PraxisReport Sozialrecht, 40/2004.

Koch E. [in:] Kasseler Kommentar zum Sozialversicherungsrecht, 112. Ergänzungslieferung, München 2021.

Koch E., Möller-Schlotfeldt A. [in:] Schulin, Handbuch des Sozialversicherungsrechts, Band 3 Rentenversicherungsrecht, $\$ 60$ Grundlagen der Alterssicherung der Landwirte, München 1999.

Landgrebe J., Sunder E., Warum braucht die landwirtschaftliche Sozialversicherung nach 2001 noch eine zweite Organisationsreform?, "Soziale Sicherheit in der Landwirtschaft” 2007.

Mell K. [in:] Schulin, Handbuch des Sozialversicherungsrechts, Band 2 Unfallversicherungsrecht, $\$ 70$ Landwirtschaftliche Unfallversicherung, München 1996.

Rombach W., Alterssicherung der Landwirte, Das neue Recht nach dem Gesetz zur Reform der Agrarsozialen Sicherung, Freiburg 1995.

165. European Network of Agricultural Protection Systems, www.enasp.eu, access 10.04.2021. 


\section{The German Social Security System for Farmers}

Schmidt B., Auf- und Ausbau des agrarsozialen Sicherungssystems im Zusammenwirken von sozialer Sicherung, Änderungen der Agrarstrukturen und finanzieller Unterstützung des Bundes, "Soziale Sicherheit in der Landwirtschaft" 2011.

Schmidt B., Sunder E., Fleuth E. et all., Hofabgabeverpflichtung auf dem Prüfstand Konsequenzen aus dem Gutachten des Thünen-Instituts zur agrarstrukturellen Wirkung der Hofabgabeverpflichtung, "Soziale Sicherheit in der Landwirtschaft" 2013.

Spitzenverbände der landwirtschaftlichen Sozialversicherung, Kurt-Wilhelm Noell und seine Gedanken und Erinnerungen zum Entstehen, der Schaffung und der Verwirklichung der agrarsozialen Sicherung im Rahmen der nationalen und internationalen Gegebenheiten 1952 bis 1977, Monographie, 2002.

Volbers W. [in:] Schulin, Handbuch des Sozialversicherungsrechts, Band 1 Krankenversicherungsrecht, $\$ 57$ Grundlagen der landwirtschaftlichen Krankenversicherung, München 1994.

Wirth C., Anhebung der Altersgrenzen in der Alterssicherung der Landwirte und weitere Änderungen im Gesetz über die Alterssicherung der Landwirte, "Soziale Sicherheit in der Landwirtschaft" 2006.

This article is licensed under a Creative Commons Attribution 4.0

International license (CC BY 4.0) 